\title{
Phenotypic Characteristics Correlated with Deoxyribonucleic Acid Sequence Similarities for Three Species of Gluconobacter: G. oxydans (Henneberg 1897) De Ley 1961, G. frateurii sp. nov., and G. asaii sp. nov.
}

\author{
LORI M. MASON AND G. WILLIAM CLAUS* \\ Microbiology and Immunology Section, Department of Biology, Virginia Polytechnic Institute and State University, \\ Blacksburg, Virginia 24061
}

\begin{abstract}
In Bergey's Manual of Systematic Bacteriology, vol. 1, only one species is listed in the genus Gluconobacter. One other species, Gluconobacter cerinus, was proposed by Yamada and Akita in 1984. However, recent deoxyribonucleic acid-deoxyribonucleic acid homology studies have produced evidence of at least three distinct homology groups that are believed to represent three species within this genus. In this paper we report results obtained by using 35 strains and 58 phenotypic characteristics. Three tests were useful in differentiating the three Gluconobacter species. Homology group I strains grew to an optical density (OD) of only $0.5 \mathrm{U}$ or less on medium containing ribitol or arabitol as the primary carbon source, and they grew to an OD of only $0.5 \mathrm{U}$ or less after three passages ( $24 \mathrm{~h}$ of incubation each) in nicotinate-deficient media. We propose that the name Gluconobacter oxydans (Henneberg 1897) De Ley 1961 be retained for these strains. Homology group II strains grew to an OD of more than $1.0 \mathrm{U}$ on medium containing ribitol or arabitol as the primary carbon source, and they grew to an OD of more than 1.0 $\mathrm{U}$ after three passages ( $24 \mathrm{~h}$ of incubation each) in nicotinate-deficient media. We propose that the group II gluconobacters be named Gluconobacter frateurii sp. nov. All of the typical strains of homology group III grew to an $\mathrm{OD}$ of $0.5 \mathrm{U}$ or less on medium containing ribitol or arabitol as the primary carbon source, but they grew to an $\mathrm{OD}$ of $1.0 \mathrm{U}$ or more after three passages ( $24 \mathrm{~h}$ of incubation each) in nicotinate-deficient media. We propose that the group III gluconobacters be named Gluconobacter asaii sp. nov.
\end{abstract}

The genus Gluconobacter is one of two industrially important genera of gram-negative rods which are placed in the family Acetobacteraceae along with the genus Acetobacter (6). The genus Gluconobacter has the following characteristics: contains straight-chain $\mathrm{C}_{16}$ and $\mathrm{C}_{18}$ fatty acids (23); oxidizes ethanol to acetic acid, but is unable to oxidize lactate or acetate completely to $\mathrm{CO}_{2}$ and water $(4,7)$; contains ubiquinone 10 as the main quinone compound (19, 20); possesses an incomplete tricarboxylic acid cycle (12); carries out single-step oxidations of various polyalcohols to their corresponding ketoses $(3,7)$; produces 2-ketogluconic acid from glucose (7); and has polar multitrichous flagella, when motile $(2,7)$.

A description of this genus was first published in Japanese in 1935 (reviewed by Asai [2]). Since 1935, the subgeneric taxonomy has remained in a state of flux. In Bergey's Manual of Determinative Bacteriology, 8th ed., which was published in 1974 (5), this genus was classified as consisting of one species, Gluconobacter oxydans (Henneberg 1897) De Ley 1961, and four subspecies, $G$. oxydans subsp. industrius, $G$. oxydans subsp. melanogenus, $G$. oxydans subsp. oxydans, and $G$. oxydans subsp. suboxydans. In 1975, a fifth subspecies, G. oxydans subsp. sphaericus, was described by Ameyama (1). Since 1975, further attempts have been made to clarify the status of species in this genus through the use of numerical analysis of phenotypic characteristics $(11,13,21)$ and, more recently, through the use of deoxyribonucleic acid (DNA)-DNA homology studies (14, 22).

In 1979, Loitsyanskaya et al. (13) used numerical tech-

\footnotetext{
* Corresponding author.
}

niques to examine 136 characteristics of 15 Gluconobacter strains and 41 Acetobacter strains. These authors found a similarity coefficient of $90 \%$ among the Gluconobacter strains, and they concluded that this genus is composed of a single species, which they called $G$. oxydans.

In 1983, Gosselé et al. (11) examined 177 phenotypic features of 98 Gluconobacter strains. These authors also concluded that too few differences occurred among these strains to separate them into more than one species, and they proposed retaining the name $G$. oxydans for the single species. However, differences in the requirement for nicotinic acid and differences in the electrophoretic protein patterns led them to propose the existence of two distinct phena, which they called phena A and B. Phenon A was characterized by its lack of a requirement for nicotinate, and phenon $\mathrm{B}$ was distinguished by its requirement for nicotinate.

The findings of Loitsyanskaya et al. (13) and Gosselé et al. (11) led Swings and De Ley, in 1984 (7), to state that the use of subspecies names should be discontinued, because the genus Gluconobacter is comprised of a continuum of strains which lack definite boundaries for either species or subspecies differentiation.

In 1984, Yamada et al. (22) used phenol extraction and the membrane filter method (16) to examine the DNA-DNA homologies of 20 Gluconobacter strains. These authors found at least two distinct homology groups within the genus. Group a was composed of strains having 46 to $82 \%$ homology with the type strain of the type species of the genus (strain ATCC $19357^{\mathrm{T}}$ [ $\mathrm{T}=$ type strain]), and group b was composed of strains having $24 \%$ or less homology with the type species. The results of this homology study and subsequent examination of the electrophoretic protein pat- 
terns of six enzymes led Yamada and Akita (21) to propose the existence of the following two distinct Gluconobacter species: (i) homology group a, which they called G. oxydans, and (ii) homology group b, which they called Gluconobacter cerinus. A comparison of these two species $(21,22)$ with the two groups described by Gosselé et al. (11) shows that the strains having higher DNA-DNA homology values (group a of Yamada et al.) require nicotinate for growth (phenon B of Gosselé et al.), while many of the strains having lower DNA-DNA homology values (group b of Yamada et al. ) lack a requirement for nicotinate (phenon A of Gosselé et al.).

Simultaneously with the study of Yamada et al. (22), Micales et al. (14) used hydroxylapatite extraction and the S1 nuclease method to determine DNA sequence similarities for 54 Gluconobacter strains. Micales et al. reported the existence of the following three distinct homology groups: group I, consisting of strains having 42 to $99 \%$ homology with the type strain of the type species for the genus and an average intragroup homology level of $86 \%$; group II, consisting of strains having 16 to $26 \%$ homology with the type strain of the type species for the genus (B. K. Micales, M.S. thesis, Virginia Polytechnic Institute and State University, Blacksburg, 1983) and an average intragroup homology level of $65 \%$ (14); and homology group III, consisting of strains having 13 to $23 \%$ homology with the type strain of the type species for the genus (Micales, M.S. thesis) and an intragroup homology level of $86 \%$ (14). The average level of relatedness among these three groups is only $16 \%$ (14). Thus, Micales et al. (14) proposed the existence of at least three species in the genus Gluconobacter, but they did not name these species.

Since DNA homology studies are not usually used for routine identification of bacterial strains, it is important to determine phenotypic traits that can be used for this purpose. Consequently, our research was directed toward determining phenotypic features that allow reliable identification of the Gluconobacter species.

(This research was conducted by Lori M. Jones-Mason in partial fulfillment of the requirements for the M.S. degree from Virginia Polytechnic Institute and State University, Blacksburg, Va., 1987. Part of this research was presented at the 87th Annual Meeting of the American Society for Microbiology, Atlanta, Ga., 1 to 6 March 1987, abstr. R-5, p. 241.)

\section{MATERIALS AND METHODS}

Bacterial strains. For our initial studies, we chose eight strains to represent the three homology groups of Micales et al. (14). Where possible, these strains were chosen to represent high, intermediate, and low levels of DNA sequence similarity within the homology groups (Table 1). After we found phenotypic tests that differentiated among the homology groups when the eight representative strains were used, we used these tests to examine 27 additional Gluconobacter strains. (For a list of all 35 strains used in this study, see Table 4.)

Culture maintenance. Working cultures were routinely maintained as liquid suspensions in $66 \%$ glycerol at $-15^{\circ} \mathrm{C}$ (18). For long-term storage, cells were suspended in $15 \%$ glycerol and stored in liquid nitrogen (18).

Colony observations. Because Gluconobacter strains often exhibit different colony types (14), colony characteristics were periodically checked by streaking organisms onto $5 \%$ sorbitol medium (14) and observing the resulting colonies after $48 \mathrm{~h}$ of incubation at $28^{\circ} \mathrm{C}$. Colonies were examined with a dissecting microscope and a high-intensity, external
TABLE 1. Representative strains examined in the initial phenotypic studies of the genus Gluconobacter

\begin{tabular}{clc}
\hline $\begin{array}{c}\text { Homology } \\
\text { group }^{a}\end{array}$ & $\begin{array}{c}\text { Representative } \\
\text { strains }^{b}\end{array}$ & $\begin{array}{c}\% \\
\text { Homology } \\
\text { to reference } \\
\text { strain }^{c}\end{array}$ \\
\hline I & ATCC 19357 & 100 \\
& IFO 3293 & 83 \\
II & ATCC 23651a & 51 \\
& IFO 3264 & 100 \\
& ATCC 15178 & 68 \\
III & IFO 3254 & 44 \\
& IFO 3276a & 100 \\
& IFO 3297a & 77 \\
\hline
\end{tabular}

${ }^{a}$ DNA-DNA homology groups as designated by Micales et al. (14).

${ }^{b}$ Strains chosen to represent the DNA-DNA homology groups of Micales et al. Abbreviations: ATCC, American Type Culture Collection, Rockville, Md.; IFO, Institute of Fermentation, Osaka, Japan; NCIB, National Collection of Industrial Bacteria, Aberdeen, Scotland. A lower-case letter at the end of a strain designation indicates one of several colony types isolated from the strain as received by Micales et al. (14) prior to determining the DNA homology of that strain.

Percentages of DNA-DNA homology, determined by using hydroxylapatite extraction and the $S 1$ nuclease method by Micales et al. (14). The values for the reference strains which were used to define the homology groups by Micales et al. are shown as $100 \%$.

${ }^{d}$ Strain IFO $3264^{\mathrm{T}}$ used in this study has recently been deposited in the American Type Culture Collection as strain ATCC $49207^{\mathrm{T}}$.

$e$ Colony variant a isolated by B. K. Micales from strain IFO $3276^{\mathrm{T}}$ and used in the DNA-DNA homology study was shown to be genetically identical to colony variant IFO $3276 \mathrm{~b}$ (14). Strain IFO $3276^{\mathrm{T}}$ (containing colony variants $a$ and $b$ ) has recently been deposited in the American Type Culture Collection as strain ATCC 49206.

light source; the variable illumination angle and intensity of the light source were set so as to best determine the color, elevation, and surface features of each colony. Then the plate was turned over to examine the undersides of the colonies with the same illumination.

Chemicals and solutions. All polyols and vitamins were obtained from Sigma Chemical Co. All medium components were obtained from Difco Laboratories unless otherwise specified. All solutions were prepared as percentages of weight per volume in double-distilled deionized water.

Selection of phenotypic characteristics. To determine which tests might successfully differentiate the three Gluconobacter homology groups, we reviewed the results of the phenotypic study performed by Gosselé et al. (11). From this study, it was apparent that the following three tests reflected differences between phenon $\mathrm{A}$ and phenon $\mathrm{B}$ : nicotinate requirement, growth on various polyols as sole carbon sources, and growth at elevated temperatures. We felt that these tests might also differentiate between two or three distinct DNA-DNA homology groups. Other tests were chosen at random or because they were part of a series of appropriate rapid tests.

Growth determinations. Unless otherwise stated, each growth determination was made in duplicate on at least three separate occasions. Liquid cultures $(6$ or $7 \mathrm{ml})$ were incubated at $28^{\circ} \mathrm{C}$ in $25-\mathrm{ml}$ test tubes (inside diameter, $1.5 \mathrm{~mm}$ ). All cultures were aerated by rotating them at $27 \mathrm{rpm}$ with a roller drum apparatus (model TC-5; New Brunswick Scientific Co., Inc.). These culture tubes were also used as cuvettes for determining the extent of growth by using a Spectronic 20 spectrophotometer (Bausch \& Lomb, Inc.) to measure optical density (OD) at a wavelength of $620 \mathrm{~nm}$. Immediate postinoculation turbidities ranged from 0.05 to 0.08 OD unit. All preparations with reported OD values which exceeded $0.4 \mathrm{U}$ were diluted 10 -fold with the sterile 
washing fluid described below for each determination to obtain more accurate measurements of culture turbidity.

Growth on polyols as primary carbon sources. A $5 \%$ sorbitol medium (14) was used to prepare inocula for all polyol studies. A $0.03-\mathrm{ml}$ portion of a working culture was inoculated into culture tubes containing $7 \mathrm{ml}$ of sorbitol medium. After the preparation reached an OD of $0.6 \mathrm{U}, 6 \mathrm{ml}$ of the culture was centrifuged for $10 \mathrm{~min}$ at $1,180 \times \mathrm{g}$. The resulting pellet was suspended in $6 \mathrm{ml}$ of a sterile washing fluid containing $0.3 \%$ vitamin-free Casamino Acids and $0.5 \%$ yeast extract. This suspension was centrifuged as described above, and the resulting pellet was then suspended in $3 \mathrm{ml}$ of the sterile washing fluid. This suspension served as the source of inocula for all polyol studies.

The basal medium for all polyol studies contained $0.3 \%$ vitamin-free Casamino Acids and $0.5 \%$ yeast extract, and this medium either lacked or contained $0.5 \%$ polyol. All polyols were prepared as $5 \%$ solutions in double-distilled deionized water and were filter sterilized. A $0.1-\mathrm{ml}$ portion of inoculum was added to $5.9 \mathrm{ml}$ of the basal medium which either contained or lacked polyol. The cultures were incubated for $24 \mathrm{~h}$, and growth was measured as described above for growth determinations.

Acid production. A $0.03-\mathrm{ml}$ portion of a working culture was inoculated into $6 \mathrm{ml}$ of a medium containing $1 \%$ yeast extract, $1 \%$ peptone, and one of the following polyols at a concentration of 5\%: ribitol, myo-inositol, glucose, lactose, mannitol, or sorbitol. Prior to autoclaving, the $\mathrm{pH}$ of each medium was adjusted to 6.0 by using concentrated hydrochloric acid. The cultures were incubated at $28^{\circ} \mathrm{C}$ with aeration as described above. The $\mathrm{pH}$ of each culture medium was determined by using a model $12 \mathrm{pH}$ meter (Corning Glass Works) at the following three stages during culture development: at an OD of 0.5 to $0.6 \mathrm{U}$; at an OD of $1.0 \mathrm{U}$; and after $72 \mathrm{~h}$ of incubation, when the OD for all strains was greater than $1.0 \mathrm{U}$.

Tolerance to sodium chloride and elevated glucose levels. Inocula were prepared as described above for growth on polyols, except that the washing fluid contained $1 \%$ yeast extract and $1 \%$ peptone, and the cells were concentrated five times. The basal medium for all tolerance studies contained $1 \%$ yeast extract and $1 \%$ peptone (final concentrations). Glucose solutions were prepared as $2 \times$ solutions, sterilized by autoclaving, cooled to room temperature, and mixed with a $2 \times$ concentration of the basal medium. Media containing different $\mathrm{NaCl}$ concentrations were prepared by adding various volumes of a $0.01 \mathrm{M} \mathrm{NaCl}$ solution directly to the basal medium and $1 \%$ mannitol prior to autoclaving. A $0.1-\mathrm{ml}$ portion of inoculum was added to $6.9 \mathrm{ml}$ of the test medium. Growth was measured, as described above for growth determinations, after 24 and $48 \mathrm{~h}$ of incubation.

Enzyme activity and biochemical tests. For enzyme activity tests in which the API ZYM rapid test procedure was used, an inoculum was prepared by adding $0.2 \mathrm{ml}$ of a working culture to a $500-\mathrm{ml}$ flask containing $50 \mathrm{ml}$ of a sterile medium composed of $5 \%$ glycerol, $1 \%$ peptone, and $1 \%$ yeast extract and adjusted to $\mathrm{pH} 6.0$ prior to autoclaving. The cultures were incubated at $28^{\circ} \mathrm{C}$ with shaking at 200 reciprocations per min in a PsychroTherm incubator (New Brunswick Scientific Co., Inc.). After reaching and OD of $1.0 \mathrm{U}, 20 \mathrm{ml}$ of a culture was centrifuged for $10 \mathrm{~min}$ at $1,180 \times \mathrm{g}$. The resulting pellet was suspended in $2 \mathrm{ml}$ of double-distilled deionized water, and a sterile Pasteur pipette was used to add 2 drops of this suspension to each well of an API ZYM strip. These suspensions were then incubated at $28^{\circ} \mathrm{C}$ for 4 to $6 \mathrm{~h}$.
For biochemical tests in which the Non-Fermentor system (Flow Laboratories, Inc.) was used, an inoculum was prepared as described above for the API ZYM tests, except that only 1 drop of culture was added to each chamber of the plate. These suspensions were incubated at $28^{\circ} \mathrm{C}$ for $24 \mathrm{~h}$.

Hydrogen sulfide production. Inocula were prepared as described above for tolerance to $\mathrm{NaCl}$ and elevated glucose levels. A $0.2-\mathrm{ml}$ portion of inoculum was then added to a 125 -ml flask containing $25 \mathrm{ml}$ of $5 \%$ sorbitol medium (14) either with or without $0.01 \%$ (wt/vol) sodium thiosulfate (Fisher Scientific Co.). The $\mathrm{H}_{2} \mathrm{~S}$ production was measured by using method 2 of Smibert and Krieg (17). All cultures were incubated for 12 days without agitation and were visually examined for blackening on the lower portion of the lead acetate strip.

Growth at various temperatures. A 6-ml portion of mannitol medium (8) was placed into each culture tube, and the preparations were autoclaved and preequilibrated to each growth temperature. A $\mathbf{0 . 0 3 - m l ~ p o r t i o n ~ o f ~ a ~ w o r k i n g ~ c u l t u r e ~}$ was used to inoculate the temperature-equilibrated media. Cultures were incubated at various temperatures, and their growth after $48 \mathrm{~h}$ of incubation was measured as described above for growth determinations.

Growth in the absence of nicotinate. Inocula were prepared as described above for tolerance to $\mathrm{NaCl}$ and elevated glucose levels, except that the washing fluid contained $1 \%$ vitamin-free Casamino Acids.

The basal medium for this study contained $1 \%$ vitaminfree Casamino Acids and 1\% mannitol adjusted to $\mathrm{pH} 6.0$. The experimental media contained $5.7 \mathrm{ml}$ of the sterile basal medium plus $0.2 \mathrm{ml}$ of one of two possible vitamin solutions. One vitamin solution contained a sufficient quantity of each vitamin to achieve the following final concentrations in the experimental medium: $0.00015 \%(\mathrm{wt} / \mathrm{vol})$ pyridoxal hydrochloride, $0.00015 \%$ (wt/vol) riboflavin, $0.0001 \%(\mathrm{wt} / \mathrm{vol}) \mathrm{bi}-$ otin, $0.0001 \%$ (wt/vol) thiamine, $0.0001 \%$ (wt/vol) pantothenic acid, and $0.0001 \%$ (wt/vol) para-aminobenzoic acid (9). We also prepared a second vitamin solution that contained the same final concentrations of all of these vitamins plus nicotinate at a final concentration of $0.00015 \%$. Both vitamin solutions were filter-sterilized prior to addition to the basal medium.

A $0.1-\mathrm{ml}$ portion of the inoculum was added to each experimental medium. After $24 \mathrm{~h}, 0.1 \mathrm{ml}$ of the first culture was directly transferred to a second tube containing the same experimental medium and incubated as before. After $24 \mathrm{~h}$ of incubation of these second cultures, $0.1 \mathrm{ml}$ of each culture was transferred to a third tube containing the same experimental medium and incubated as before. After $24 \mathrm{~h}$ of incubation of these third cultures, growth was measured as described above for growth determinations.

\section{RESULTS}

Nondifferential characteristics. Using eight representative strains from the three Gluconobacter homology groups, we found 39 phenotypic tests that did not clearly differentiate one group from the others. However, these results are summarized in Table 2 because (i) certain characteristics appear to be common to all strains regardless of their homology group and should be of value for further characterization of this genus, (ii) one commonly shared characteristic $\left(\mathrm{H}_{2} \mathrm{~S}\right.$ production) opens new questions about the metabolic capabilities of this genus, and (iii) the strain-specific characteristics should be helpful in identifying some strains.

All eight representative strains listed in Table 1 were positive for the following characteristics: (i) acid production 
TABLE 2. Characteristics which failed to differentiate among the representative strains ${ }^{a}$

\begin{tabular}{|c|c|c|c|}
\hline \multirow{2}{*}{ Test } & \multicolumn{3}{|c|}{$\begin{array}{l}\text { No. of positive strains/ } \\
\text { total no. of strains tested }\end{array}$} \\
\hline & $\begin{array}{c}\text { Group } \\
\text { I }\end{array}$ & $\begin{array}{c}\text { Group } \\
\text { II }\end{array}$ & $\begin{array}{c}\text { Group } \\
\text { III }\end{array}$ \\
\hline \multicolumn{4}{|l|}{ Growth on polyols ${ }^{b}$} \\
\hline Glucose & $1 / 3$ & $3 / 3$ & $1 / 2$ \\
\hline Sucrose & $0 / 3$ & $0 / 3$ & $0 / 2$ \\
\hline myo-Inositol & $0 / 3$ & $2 / 3$ & $1 / 2$ \\
\hline Xylitol & $0 / 3$ & $3 / 3$ & $1 / 2$ \\
\hline \multicolumn{4}{|l|}{ Acid production from polyols ${ }^{c}$} \\
\hline Glucose & $3 / 3$ & $3 / 3$ & $2 / 2$ \\
\hline Xylose & $3 / 3$ & $3 / 3$ & $2 / 2$ \\
\hline Maltose & $3 / 3$ & $3 / 3$ & $2 / 2$ \\
\hline Sorbitol & $3 / 3$ & $3 / 3$ & $1 / 2$ \\
\hline Mannitol & $3 / 3$ & $3 / 3$ & $1 / 2$ \\
\hline Lactose & $3 / 3$ & $3 / 3$ & $1 / 2$ \\
\hline Ribitol & $3 / 3$ & $3 / 3$ & $1 / 2$ \\
\hline myo-Inositol & $3 / 3$ & $3 / 3$ & $1 / 2$ \\
\hline \multicolumn{4}{|l|}{ Tolerance to glucose $\mathrm{e}^{d}$} \\
\hline $10 \%$ & $3 / 3$ & $3 / 3$ & $2 / 2$ \\
\hline $15 \%$ & $2 / 3$ & $3 / 3$ & $1 / 2$ \\
\hline $17 \%$ & $1 / 3$ & $3 / 3$ & $1 / 2$ \\
\hline $19 \%$ & $0 / 3$ & $2 / 3$ & $1 / 2$ \\
\hline $20 \%$ & $0 / 3$ & $2 / 3$ & $0 / 2$ \\
\hline $25 \%$ & $0 / 3$ & $0 / 3$ & $0 / 2$ \\
\hline $30 \%$ & $0 / 3$ & $0 / 3$ & $0 / 2$ \\
\hline \multicolumn{4}{|l|}{ Tolerance to $\mathrm{NaCl}^{d}$} \\
\hline $0.5 \%$ & $3 / 3$ & $3 / 3$ & $2 / 2$ \\
\hline $0.75 \%$ & $3 / 3$ & $3 / 3$ & $2 / 2$ \\
\hline $1.0 \%$ & $3 / 3$ & $3 / 3$ & $1 / 2$ \\
\hline $1.2 \%$ & $2 / 3$ & $2 / 3$ & $2 / 2$ \\
\hline $1.4 \%$ & $2 / 3$ & $1 / 3$ & $0 / 2$ \\
\hline $1.5 \%$ & $0 / 3$ & $0 / 3$ & $0 / 2$ \\
\hline $2.0 \%$ & $0 / 3$ & $0 / 3$ & $0 / 2$ \\
\hline Hydrogen sulfide production ${ }^{e}$ & $3 / 3$ & $3 / 3$ & $2 / 2$ \\
\hline \multicolumn{4}{|c|}{ Enzyme activities (API ZYM system) ${ }^{f}$} \\
\hline Esterase-lipase & $3 / 3$ & $3 / 3$ & $2 / 2$ \\
\hline Leucine aminopeptidase & $3 / 3$ & $3 / 3$ & $2 / 2$ \\
\hline Valine aminopeptidase & $3 / 3$ & $3 / 3$ & $2 / 2$ \\
\hline Acid phosphatase & $3 / 3$ & $3 / 3$ & $2 / 2$ \\
\hline Phosphohydrolase & $3 / 3$ & $3 / 3$ & $2 / 2$ \\
\hline$N$-acetyl- $\beta$-glucosaminidase & $3 / 3$ & $3 / 3$ & $2 / 2$ \\
\hline Lipase & $0 / 3$ & $0 / 3$ & $0 / 2$ \\
\hline$\alpha$-Galactosidase & $0 / 3$ & $0 / 3$ & $0 / 2$ \\
\hline$\beta$-Galactosidase & $0 / 3$ & $0 / 3$ & $0 / 2$ \\
\hline$\beta$-Glucuronidase & $0 / 3$ & $0 / 3$ & $0 / 2$ \\
\hline$\beta$-Glucosidase & $0 / 3$ & $0 / 3$ & $0 / 2$ \\
\hline$\alpha$-Mannosidase & $0 / 3$ & $0 / 3$ & $0 / 2$ \\
\hline$\alpha$-Fucosidase & $0 / 3$ & $0 / 3$ & $0 / 2$ \\
\hline$\alpha$-Glucosidase & $1 / 3$ & $0 / 3$ & $0 / 2$ \\
\hline Esterase & $1 / 3$ & $0 / 3$ & $0 / 2$ \\
\hline Alkaline phosphatase & $0 / 3$ & $1 / 3$ & $0 / 2$ \\
\hline Cystine aminopeptidase & $3 / 3$ & $3 / 3$ & $1 / 2$ \\
\hline Trypsin & $3 / 3$ & $3 / 3$ & $1 / 2$ \\
\hline Chymotrypsin & $3 / 3$ & $3 / 3$ & $1 / 2$ \\
\hline \multicolumn{4}{|c|}{$\begin{array}{l}\text { Enzyme activities (Flow Laboratories } \\
\text { Non-Fermentor system) }\end{array}$} \\
\hline Acetamide hydrolysis & $0 / 3$ & $0 / 3$ & $0 / 2$ \\
\hline Esculin hydrolysis & $0 / 3$ & $0 / 3$ & $0 / 2$ \\
\hline Urea hydrolysis & $0 / 3$ & $0 / 3$ & $0 / 2$ \\
\hline Deoxyribonuclease & $0 / 3$ & $0 / 3$ & $0 / 2$ \\
\hline$\beta$-Galactosidase & $0 / 3$ & $0 / 3$ & $0 / 2$ \\
\hline \multicolumn{4}{|l|}{ Temperature studies $^{h}$} \\
\hline $33^{\circ} \mathrm{C}$ & $2 / 3$ & $3 / 3$ & $1 / 2$ \\
\hline $34^{\circ} \mathrm{C}$ & $2 / 3$ & $3 / 3$ & $1 / 2$ \\
\hline $35^{\circ} \mathrm{C}$ & $0 / 3$ & $0 / 3$ & $1 / 2$ \\
\hline $37^{\circ} \mathrm{C}$ & $0 / 3$ & $0 / 3$ & $1 / 2$ \\
\hline
\end{tabular}

during growth on glucose, xylose, and maltose; (ii) growth on complex media containing $10 \%$ glucose; (iii) growth on mannitol media containing $0.75 \% \mathrm{NaCl}$; (iv) $\mathrm{H}_{2} \mathrm{~S}$ production on sorbitol media containing thiosulfate; and (v) esteraselipase, leucine aminopeptidase, valine aminopeptidase, phosphohydrolase, and $N$-acetyl- $\beta$-glucosaminidase activities.

All eight representative strains were negative for the following characteristics: (i) growth on complex media containing sucrose as the primary carbon source; (ii) growth on complex media containing $25 \%$ glucose; (iii) growth on mannitol media containing $1.5 \% \mathrm{NaCl}$; (iv) lipase, $\alpha$ - and $\beta$-galactosidase, $\beta$-glucuronidase, $\alpha$-mannosidase, $\alpha$-fucosidase, and deoxyribonuclease activities; and ( $v$ ) acetamide, esculin, and urea hydrolysis.

Strain IFO 3297a was the only strain that increased the $\mathrm{pH}$ from 6.0 to 7.0 or above when it was grown on sorbitol, mannitol, lactose, ribitol, or myo-inositol as the primary carbon source, and it was the only strain to grow to an OD of $1.0 \mathrm{U}$ or more at $37^{\circ} \mathrm{C}$.

Differential characteristics. (i) Growth on ribitol (adonitol). After $24 \mathrm{~h}$ of incubation, all three representative strains in homology group II grew to an OD of $2.3 \mathrm{U}$ or more on ribitol as a primary carbon source, while all of the representative strains in homology groups I and III grew to an OD of only $0.6 \mathrm{U}$ or less (Table 3). Because this characteristic appeared to differentiate homology group II from groups I and III, the 27 other strains were examined. All seven additional group II strains but only one of the three additional group III strains (IFO 3265) grew to an OD of $1.0 \mathrm{U}$ or more, whereas the 17 additional strains in homology group $I$ and two of the additional three strains in homology group III grew to an OD of only $0.5 \mathrm{U}$ or less (Table 4). Therefore, growth on ribitol to an OD of more than $1.0 \mathrm{U}$ was characteristic of homology group II strains, with only 1 exception out of the 35 strains examined. This exception, strain IFO 3265, was shown by Micales et al. (14) to have only one colony type, but it exhibits mixed homology with groups II and III, and we do not believe that it is representative of group III gluconobacters.

(ii) Growth on arabitol. After $24 \mathrm{~h}$ of incubation, all three representative strains in homology group II grew to an OD of more than $2.5 \mathrm{U}$ on medium containing arabitol as the primary carbon source, while all representative strains in homology groups I and III produced OD values of only 0.07 $\mathrm{U}$ or less (Table 3). Because this characteristic also appeared to differentiate homology group II strains from strains in groups I and III, the 27 additional strains were examined. All of the additional group II strains but only one of the three additional group III strains (IFO 3265) reached an OD of 1.0

\footnotetext{
a The eight representative strains tested are listed in Table 1 . All tests were performed at $28^{\circ} \mathrm{C}$ as described in Materials and Methods unless otherwise indicated.

${ }^{b}$ Positive strains are strains which grew to an OD of $1.0 \mathrm{U}$ or more after 24 $h$ of incubation.

${ }^{c}$ Positive strains are strains which lowered the $\mathrm{pH}$ from 6.0 to 5.0 or below after $72 \mathrm{~h}$ of incubation.

${ }^{d}$ Positive strains are strains which grew to an OD of $0.5 \mathrm{U}$ or more after 48 $\mathrm{h}$ of incubation.

${ }^{e}$ Positive strains are strains which blackened the lower portion of the lead acetate-soaked filter paper strip within 12 days after inoculation.

$f$ Positive strains are strains which gave positive results when we used the Analytlab Products API ZYM rapid test after 4 to $6 \mathrm{~h}$ of incubation.

${ }^{g}$ Positive strains are strains which gave positive results when we used the Flow Laboratories non-fermentor system after $24 \mathrm{~h}$ of incubation.

$h$ Positive strains are strains which grew to an OD of $1.0 \mathrm{U}$ or more after 48 $h$ of incubation.
} 
TABLE 3. Growth of representative strains on ribitol or arabitol as the primary carbon source ${ }^{a}$

\begin{tabular}{|c|c|c|c|c|c|c|}
\hline \multirow{3}{*}{$\begin{array}{l}\text { Homology } \\
\text { group }\end{array}$} & \multirow{3}{*}{ Strain } & \multirow{3}{*}{ Exp } & \multicolumn{4}{|c|}{ OD (U) } \\
\hline & & & \multicolumn{2}{|c|}{ Growth on ribitol } & \multicolumn{2}{|c|}{ Growth on arabitol } \\
\hline & & & $\begin{array}{c}\text { Replicate } \\
1\end{array}$ & $\begin{array}{c}\text { Replicate } \\
2\end{array}$ & $\begin{array}{c}\text { Replicate } \\
1\end{array}$ & $\begin{array}{c}\text { Replicate } \\
2\end{array}$ \\
\hline \multirow[t]{9}{*}{ I } & \multirow[t]{3}{*}{ ATCC $19357^{\mathrm{T}}$} & A & 0.49 & 0.49 & 0.02 & 0.02 \\
\hline & & B & 0.41 & 0.41 & 0.00 & 0.00 \\
\hline & & $\mathrm{C}$ & 0.20 & 0.20 & 0.06 & 0.07 \\
\hline & \multirow[t]{3}{*}{ ATCC 23651a } & A & 0.32 & 0.32 & 0.00 & 0.00 \\
\hline & & B & 0.30 & 0.30 & 0.00 & 0.00 \\
\hline & & $\mathrm{C}$ & 0.31 & 0.31 & 0.00 & 0.00 \\
\hline & \multirow[t]{3}{*}{ IFO 3293} & A & 0.53 & 0.53 & 0.00 & 0.00 \\
\hline & & B & 0.45 & 0.45 & 0.00 & 0.00 \\
\hline & & $\mathrm{C}$ & 0.46 & 0.46 & 0.00 & 0.00 \\
\hline \multirow{9}{*}{ II } & \multirow{3}{*}{ ATCC 15178} & A & 2.60 & 2.60 & 2.80 & 2.80 \\
\hline & & B & 2.50 & 2.50 & 2.90 & 2.90 \\
\hline & & $\mathrm{C}$ & 2.80 & 2.80 & 3.10 & 3.10 \\
\hline & \multirow[t]{3}{*}{ IFO 3254} & $\mathrm{~A}$ & 2.70 & 2.70 & 3.00 & 3.00 \\
\hline & & B & 2.30 & 2.30 & 2.90 & 2.90 \\
\hline & & $\mathrm{C}$ & 2.80 & 2.80 & 3.40 & 3.40 \\
\hline & \multirow{3}{*}{ IFO $3264^{\mathrm{T}}\left(=\right.$ ATCC $\left.49207^{\mathrm{T}}\right)$} & A & 3.00 & 3.00 & 4.50 & 4.50 \\
\hline & & B & 2.50 & 2.50 & 2.80 & 2.80 \\
\hline & & $\mathrm{C}$ & 3.00 & 3.00 & 3.20 & 3.20 \\
\hline \multirow[t]{6}{*}{ III } & \multirow[t]{3}{*}{ IFO $3276 \mathrm{a}^{b}$} & A & 0.31 & 0.31 & 0.00 & 0.00 \\
\hline & & B & 0.29 & 0.29 & 0.00 & 0.00 \\
\hline & & C & 0.29 & 0.29 & 0.00 & 0.00 \\
\hline & \multirow[t]{3}{*}{ IFO $3297 a$} & $\mathrm{~A}$ & 0.02 & 0.02 & 0.04 & 0.04 \\
\hline & & B & 0.09 & 0.09 & 0.00 & 0.00 \\
\hline & & $\mathrm{C}$ & 0.01 & 0.01 & 0.00 & 0.00 \\
\hline
\end{tabular}

${ }^{a}$ All strains were grown in a medium containing $0.5 \%(\mathrm{wt} / \mathrm{vol})$ yeast extract, $0.3 \%(\mathrm{wt} / \mathrm{vol})$ peptone, and either $0.5 \%(\mathrm{wt} / \mathrm{vol}) \mathrm{ribitol}$ or $0.5 \%$ (wt/vol) arabitol as described in Materials and Methods. Cultures were incubated for $24 \mathrm{~h}$ at $28^{\circ} \mathrm{C}$ and aerated on a roller drum tube apparatus set at 27 rpm.

$b$ Colony variant a isolated by B. K. Micales from strain IFO $3276^{\mathrm{T}}$ and used in the DNA-DNA homology study was shown to be genetically identical to colony variant IFO $3276 \mathrm{~b}$ (14). Strain IFO $3276^{\mathrm{T}}$ (containing colony variants a and b) has recently been deposited in the American Type Culture Collection as strain ATCC $49206^{\mathrm{T}}$.

$\mathrm{U}$, while the 17 additional strains in homology group $\mathrm{I}$ and the two remaining group III strains grew to an OD of only 0.1 $\mathrm{U}$ or less (Table 4). Therefore, growth on arabitol to an OD of more than $1.0 \mathrm{U}$ was characteristic of homology group II strains, with only 1 exception out of the 35 strains examined; this exception (strain IFO 3265) is the strain with mixed DNA-DNA homology (14).

(iii) Growth in the absence of nicotinic acid. When we inoculated washed cells from a complex medium into a nicotinate-deficient medium, representative strains from homology group I grew as much as 0.75 OD unit after $24 \mathrm{~h}$ of incubation (data not shown). When these cultures were successively transferred two more times to nicotinate-deficient media and incubated for $24 \mathrm{~h}$ after each transfer, group I representative strains grew to a maximum OD of only $0.4 \mathrm{U}$ (Table 5). Therefore, it appeared that three transfers into nicotinate-deficient media were necessary to show the effect of nicotinate absence on growth. When the group I representative strains were allowed to grow for a total of $48 \mathrm{~h}$ after the third transfer, culture OD values reached at least $1.5 \mathrm{U}$ (data not shown). This indicated that the incubation time needed to be limited to $24 \mathrm{~h}$ after the third transfer to show the effect of nicotinate deficiency on growth. In contrast to the limited growth of the group I representative strains, four of the five group II and III representative strains grew to an OD of at least $1.9 \mathrm{U}$ after three successive transfers and 24 $h$ of incubation in nicotinate-deficient media (Table 5). Therefore, our results suggested that $24 \mathrm{~h}$ of growth after three successive transfers into nicotinate-deficient media allowed differentiation of group I gluconobacters from strains in groups II and III.
When the remaining 27 strains were examined (Table 4), 15 of the 17 remaining group I strains either failed to grow or grew to an OD of only $0.4 \mathrm{U}$ or less. The remaining strains (strains ATCC 23652 and IFO 3275a) reached OD values of between 0.5 and $1.0 \mathrm{U}$. All of the remaining group III strains and all but one of the seven additional group II strains (IFO 3272) grew to an OD of $1.8 \mathrm{U}$ or more. Therefore, growth to an OD of $0.5 \mathrm{U}$ or less after three successive transfers in nicotinate-deficient media and $24 \mathrm{~h}$ of incubation was characteristic of strains in homology group I, whereas growth to an OD of more than $1.0 \mathrm{U}$ was characteristic of strains in homology groups II and III. At present we know of only two exceptions to this conclusion. Strain IFO 3297a (homology group III) showed poor growth both in the presence and in the absence of nicotinate (Table 5), and strain IFO 3272 (homology group II) grew to an OD of $0.7 \mathrm{U}$ or less in the presence of nicotinate (Table 4). Thus, it appeared that these two strains have nutritional requirements that are not provided by the medium used in our study.

(iv) Strains with special nutritional requirements. Of the 35 strains used in this study, 4 (strains ATCC 23760, IFO 3272, IFO $3297 \mathrm{a}$, and IFO $3297 \mathrm{~b}$ ) grew to an OD of only $0.7 \mathrm{U}$ or less after three passes in the semidefined medium used in our nicotinate study, which contained pyridoxal hydrochloride, riboflavin, biotin, thiamine, pantothenate, para-aminobenzoate, and nicotinate. However, all four of these strains grew to an OD of $1.0 \mathrm{U}$ or more in a medium that contained yeast extract as an undefined source of vitamins (data not shown). Neither the addition of $0.00015 \%$ vitamin $B_{12}$, $0.00015 \%$ folic acid, and $0.00015 \%$ pantethine to the medium nor the substitution of peptone for Casamino Acids caused 
TABLE 4. Summary of phenotypic characteristics for all Gluconobacter strains examined

\begin{tabular}{|c|c|c|c|c|c|c|c|c|}
\hline \multirow[b]{2}{*}{ Species } & \multirow{2}{*}{$\begin{array}{l}\text { Homology } \\
\text { group of } \\
\text { Micales } \\
\text { et al. }{ }^{a}\end{array}$} & \multirow[b]{2}{*}{ Strain $^{b}$} & \multirow{2}{*}{$\begin{array}{l}\text { Other strain } \\
\text { designation }\end{array}$} & \multirow{2}{*}{$\begin{array}{l}\text { Phenon of } \\
\text { Gosselé } \\
\text { et al. }{ }^{c}\end{array}$} & \multirow{2}{*}{$\begin{array}{l}\text { Homology } \\
\text { group of } \\
\text { Yamada } \\
\text { et al. } .^{c}\end{array}$} & \multicolumn{3}{|c|}{ Phenotypic characteristics $^{d}$} \\
\hline & & & & & & $\begin{array}{l}\text { Growth on } \\
\text { ribitol }\end{array}$ & $\begin{array}{c}\text { Growth on } \\
\text { arabitol }\end{array}$ & $\begin{array}{c}\text { Growth without } \\
\text { nicotinate }\end{array}$ \\
\hline \multirow{20}{*}{$\begin{array}{l}\text { G. oxydans } \\
\text { (Henneberg 1897) } \\
\text { De Ley } 1961\end{array}$} & \multirow[t]{20}{*}{ I } & ATCC 621 & NCIB 621 & B & NT & - & - & - \\
\hline & & ATCC $621 \mathrm{H}$ & NCIB 8036 & NT & NT & - & - & - \\
\hline & & ATCC 9937 & & NT & NT & - & - & - \\
\hline & & ATCC 14960 & NCIB 9137 & B & NT & - & - & - \\
\hline & & $\operatorname{ATCC} 19357^{\mathrm{T}}$ & NCIB $9013^{T}$ & B & $\mathrm{a}$ & - & - & - \\
\hline & & ATCC 23651a & NCIB 9014 & B & NT & - & - & - \\
\hline & & ATCC $23651 b$ & NCIB 9014 & B & NT & - & - & - \\
\hline & & ATCC 23652 & NCIB 9119 & B & NT & - & - & $\mathrm{d}$ \\
\hline & & ATCC 23760 & & NT & NT & - & - & - \\
\hline & & ATCC 23771 & NCIB 3734 & B & NT & - & - & - \\
\hline & & ATCC 33447 & LMD 29.2 & $\mathrm{~B}$ & NT & - & - & - \\
\hline & & CIP 5714 & & NT & NT & - & - & - \\
\hline & & CSIRO B1507 & & NT & NT & - & - & - \\
\hline & & IFO 3244 & & B & $\mathrm{a}$ & - & - & - \\
\hline & & IFO 3250 & & NT & a & - & - & - \\
\hline & & IFO 3275a & & NT & $\mathrm{b}$ & - & - & d \\
\hline & & IFO 3293 & & B & a & - & - & - \\
\hline & & IFO 3294 & & A & a & - & - & - \\
\hline & & IFO $3297 b$ & & NT & NT & - & - & - \\
\hline & & IFO 12528 & & $\mathrm{~B}$ & NT & - & - & - \\
\hline \multirow{10}{*}{$\begin{array}{l}G . \text { frateurii sp. } \\
\text { nov. }\end{array}$} & \multirow[t]{10}{*}{ II } & ATCC 12302 & IFO 3260 & A & b & + & + & + \\
\hline & & ATCC 15178 & & A & NT & + & + & + \\
\hline & & ATCC 15180 & & A & NT & + & + & + \\
\hline & & IFO 3251 & & A & $\mathrm{b}$ & + & + & + \\
\hline & & IFO 3254 & & N'T & $\mathrm{b}$ & + & + & + \\
\hline & & IFO $3264^{\mathrm{T}}$ & ATCC $49207^{\mathrm{T}}$ & A & $\mathrm{b}$ & + & + & + \\
\hline & & IFO 3268 & & A & $\mathrm{b}$ & + & + & + \\
\hline & & IFO 3270 & & A & b & + & + & + \\
\hline & & IFO 3272 & & NT & b & + & + & - \\
\hline & & IFO 3286 & & A & $\mathrm{b}$ & + & + & + \\
\hline \multirow{5}{*}{$\begin{array}{l}\text { G. asaii } \\
\text { sp. nov. }\end{array}$} & \multirow[t]{5}{*}{ III } & IFO $3265^{e}$ & & A & $b$ & $+^{e}$ & $t^{e}$ & $t^{e}$ \\
\hline & & IFO $3276 \mathrm{a}^{f}$ & ATCC $49206^{\mathrm{T}}$ & A & b & - & - & + \\
\hline & & IFO $3276 \mathrm{~b}^{f}$ & ATCC $49206^{\mathrm{T}}$ & A & $\mathrm{b}$ & - & - & + \\
\hline & & IFO $3297 a^{g}$ & & NT & NT & - & - & $-g$ \\
\hline & & RS203b & ATCC 43781 & NT & NT & - & - & + \\
\hline
\end{tabular}

${ }^{a}$ See reference 14.

${ }^{b}$ Abbreviations for culture collections are explained in Table 1, footnote $b$. Strain RS203b is one colony type isolated by Micales et al. (14) from a culture obtained from K. G. Rohrbach, Department of Plant Pathology, University of Hawaii at Manoa, Honolulu; this culture has recently been deposited with the American Type Culture Collection as strain ATCC 43781. Lower-case letters at the ends of strain designations indicate colony types isolated by B. K. Micales and used in our previous DNA-DNA homology study.

${ }^{c}$ NT, Strain not tested by Gosselé et al. (11) or Yamada et al. (22).

$d+$, Growth to an OD of $1.0 \mathrm{U}$ or more within $24 \mathrm{~h} ;-$, growth to an OD of $0.5 \mathrm{U}$ or less within $24 \mathrm{~h} ; \mathrm{d}$, growth to an OD between 0.5 and $1.0 \mathrm{U}$ within 24 h. See Materials and Methods for the exact procedures used and the methods of analysis.

${ }^{e}$ Micales et al. (14) gave data that suggested that this strain is a mixture of cells from homology groups II and III, but only one colony type was detected. Because of reasons given in the Discussion, we recommend that this strain not be used in further taxonomic studies.

${ }_{f}$ Micales et al. (14) found that the two colony types isolated from the strain received as IFO $3276^{\mathrm{T}}$ (called IFO 3276a and IFO 3276b) has identical DNA-DNA homologies. Strain IFO $3276^{\mathrm{T}}$ (containing both colony variants) has been deposited in the American Type Culture Collection as strain ATCC 49206 ${ }^{\mathrm{T}}$.

${ }^{8}$ Although this strain does not grow after three passages in the absence of nicotinate, it does have other characteristics that allow easy phenotypic differentiation from G. oxydans (see Discussion).

an increase in the extent of growth. Thus, it appeared that some acetic acid bacteria require unknown growth factors which are present in yeast extract but were not present in our semidefined medium. A similar conclusion was reached by Rao and Stokes (15) in their nutritional studies.

\section{DISCUSSION}

Colony variants and culture purity. We have previously found that Gluconobacter strains from many of the reputable culture collections in the world contain more than one colony type, but, because of small colony sizes, these differences may not be determined without careful microscopic examination (14). The work of Micales et al. (14) demonstrated the following with regard to these multiple colony types. (i) Some cultures contain multiple colony types that can be easily separated, and each colony type exhibits the same morphology throughout many transfers (these strains are identified [14] by adding lower-case letters to the strain designations, such as IFO 3276a). (ii) At times, a comparison of levels of DNA homology shows that separated colony types are genetically identical colony variants (such as IFO 3276a and IFO 3276b). (iii) Other times, DNA comparisons show that separated colony types are members of two distinct gluconobacter homology groups (such as IFO 3297a and IFO 3297b). (iv) Occasionally, only one of the separated colony types appears to fit into a gluconobacter 
TABLE 5. Growth of representative strains after three transfers in media lacking nicotinate ${ }^{a}$

\begin{tabular}{|c|c|c|c|c|}
\hline \multirow[b]{2}{*}{$\begin{array}{l}\text { Homology } \\
\text { group }\end{array}$} & \multirow[b]{2}{*}{ Strain } & \multirow[b]{2}{*}{ Exp } & \multicolumn{2}{|c|}{$\mathrm{OD}(\mathrm{U})$} \\
\hline & & & $\begin{array}{c}\text { Replicate } \\
1\end{array}$ & $\begin{array}{c}\text { Replicate } \\
2\end{array}$ \\
\hline \multirow[t]{9}{*}{ I } & ATCC $19357^{\mathrm{T}}$ & A & 0.17 & 0.17 \\
\hline & & B & 0.00 & 0.00 \\
\hline & & $\mathrm{C}$ & 0.00 & 0.00 \\
\hline & ATCC 23561a & A & 0.02 & 0.02 \\
\hline & & B & 0.01 & 0.08 \\
\hline & & $\mathrm{C}$ & 0.01 & 0.09 \\
\hline & IFO 3293 & A & 0.34 & 0.34 \\
\hline & & B & 0.00 & 0.00 \\
\hline & & $\mathrm{C}$ & 0.12 & 0.10 \\
\hline \multirow[t]{9}{*}{ II } & IFO $3264^{\mathrm{T}}\left(=\right.$ ATCC $\left.49207^{\mathrm{T}}\right)$ & A & 1.90 & 1.90 \\
\hline & & B & 2.10 & 2.00 \\
\hline & & $\mathrm{C}$ & 1.50 & 1.80 \\
\hline & ATCC 15178 & A & 2.90 & 2.80 \\
\hline & & B & 3.10 & 3.00 \\
\hline & & $\mathrm{C}$ & 2.80 & 2.80 \\
\hline & IFO 3254 & A & 2.30 & 2.30 \\
\hline & & B & 2.50 & 2.70 \\
\hline & & $\mathrm{C}$ & 2.20 & 2.40 \\
\hline \multirow[t]{6}{*}{ III } & IFO $3276 \mathrm{a}^{b}$ & A & 2.50 & 2.30 \\
\hline & & B & 2.00 & 2.00 \\
\hline & & $\mathrm{C}$ & 2.20 & 1.90 \\
\hline & IFO $3297 \mathrm{a}$ & A & 0.27 & 0.27 \\
\hline & & B & 0.17 & 0.17 \\
\hline & & $\mathrm{C}$ & 0.32 & 0.32 \\
\hline
\end{tabular}

"Strains were transferred to and incubated three times in a medium composed of $1 \%(\mathrm{wt} / \mathrm{vol})$ vitamin-free Casamino Acids, $1 \%(\mathrm{wt} / \mathrm{vol})$ mannitol, $0.00015 \%(\mathrm{wt} / \mathrm{vol})$ pyridoxal hydrochloride, $0.00015 \%(\mathrm{wt} / \mathrm{vol})$ riboflavin, $0.0001 \%(\mathrm{wt} / \mathrm{vol})$ biotin, $0.0001 \%(\mathrm{wt} / \mathrm{vol})$ thiamine, $0.0001 \%(\mathrm{wt} / \mathrm{vol}) \mathrm{pan}-$ tothenic acid, and $0.0001 \%(\mathrm{wt} / \mathrm{vol}) p$-aminobenzoic acid. After the fourth successive transfer, growth was measured as described in Materials and Methods. All strains were incubated for $24 \mathrm{~h}$ at $28^{\circ} \mathrm{C}$ and aerated at $27 \mathrm{rpm}$ on a roller drum tube apparatus.

${ }^{b}$ Colony variant a isolated by B. K. Micales from strain IFO $3276^{\mathrm{T}}$ and used in the DNA-DNA homology study was shown to be genetically identical to colony variant IFO $3276 \mathrm{~b}$ (14). Strain IFO $3276^{\mathrm{T}}$ (containing colony variants $a$ and $b$ ) has recently been deposited in the American Type Culture Collection as strain ATCC $49206^{\mathrm{T}}$.

homology group (such as UQM 15a). Micales et al. (14) worked only with cultures that exhibited one colony type or with cultures that could be separated and continued to form only one colony type after many transfers. We did the same in the study reported here.

Another observation made and discussed by Micales et al. (14) and reaffirmed during our study was the following: sometimes a separated colony type exhibits the same characteristics after many transfers and storage at $4^{\circ} \mathrm{C}$ on slants or at $-10^{\circ} \mathrm{C}$ in $66 \%$ glycerol; however, the other colony type may reappear when the culture is recovered after long-term storage in liquid nitrogen. The possible reasons for this phenomenon have been discussed previously (14). We only emphasize that it is important for those investigators working with gluconobacter cultures to periodically make a close examination of their cultures for purity.

Nondifferential tests and hydrogen sulfide production. When results of tests in which the eight representative strains were used demonstrated no clear differences among the homology groups (Table 2), we did not examine the remaining 27 strains.

One nondifferential test result was of interest, however, because it seemed to conflict with a previously described characteristic of the genus Gluconobacter. We observed that all eight representative strains produced $\mathrm{H}_{2} \mathrm{~S}$ (Table 2), but the genus Gluconobacter is reportedly $\mathrm{H}_{2} \mathrm{~S}$ negative (7). This genus characteristic was determined by Gosselé et al. (11), who tested for $\mathrm{H}_{2} \mathrm{~S}$ formation by using the filter paper strip method above an unbuffered medium continuing $5 \%$ glucose, $0.5 \%$ peptone, $0.5 \%$ yeast extract, $0.1 \%$ L-cysteine, and $0.05 \% \mathrm{Na}_{2} \mathrm{SO}_{4}$ adjusted to $\mathrm{pH} 7$. Our method was similar, except that we used sorbitol (because its single-step oxidation product, sorbose, dose not change the medium $\mathrm{pH}$ ), we added more peptone $(1 \%, \mathrm{wt} / \mathrm{vol})$ and yeast extract $(1 \%$, $\mathrm{wt} / \mathrm{vol}$ ), we did not add cysteine, and we used $0.01 \%$ sodium thiosulfate as a source of oxidized sulfur.

All of our cultures blackened the bottoms of the filter paper strips only when thiosulfate was present in the medium. This evidence suggests that $\mathrm{H}_{2} \mathrm{~S}$ formation occurred as a result of sulfate reduction and not as a result of oxidation of sulfhydryl-containing amino acids present in the medium. Why was $\mathrm{H}_{2} \mathrm{~S}$ formation not detected in the study of Gosselé et al. (11)? There are at least two possible explanations for this. It may be that their cells did not remain viable long enough to exhibit $\mathrm{H}_{2} \mathrm{~S}$ formation, because of the large drop in $\mathrm{pH}$ that one would expect to occur in their unbuffered glucose-containing medium. In our study with the eight indicator strains, positive results for $\mathrm{H}_{2} \mathrm{~S}$ formation did not appear until 5 days (IFO 3276a), 7 days (ATCC $19357^{\mathrm{T}}$, ATCC 23651a, IFO $3264^{\mathrm{T}}$ ), 9 days (IFO 3293, IFO 3254 , IFO 3297a), or 12 days (ATCC 15178) after inoculation. It may also be that the gluconobacters cannot reduce sulfate all the way to hydrogen sulfide.

Our results show that it is no longer correct to state that this genus is ". . . negative . . for $\mathrm{H}_{2} \mathrm{~S}$ production" (7). Each of the eight representative strains studied here formed $\mathrm{H}_{2} \mathrm{~S}$ in the presence (but not in the absence) of thiosulfate (Table 2). Since these eight strains represent the three homology groups of gluconobacters detected by Micales et al. (14), we strongly suspect that $\mathrm{H}_{2} \mathrm{~S}$ formation from thiosulfate is a characteristic of the entire genus. Since the reduction of oxidized forms of sulfur is characteristic of anaerobic respiration, this finding of thiosulfate reduction to sulfide should cast some doubt upon the ". . . strictly aerobic . . ." (7) nature of the genus Gluconobacter, and this topic should be investigated further.

Homology group I. (i) Comparison with previous studies. A total of 20 strains from homology group I of Micales et al. (14) were examined for growth in medium containing ribitol or arabitol as a primary carbon source and growth in the absence of nicotinate. All of these strains grew to an OD of $1.0 \mathrm{U}$ or less within $24 \mathrm{~h}$ in the presence of ribitol or arabitol as the primary carbon source or after three transfers into nicotinate-deficient media (Table 4). Among these 20 homology group I strains, 11 examined were previously in a phenotypic study by Gosselé et al. (11). These authors placed 10 of these 11 strains in their phenon B, which requires nicotinate for growth. The remaining strain, IFO 3294, was placed in their phenon A, which does not require nicotinate for growth. However, Micales et al. (14) found that strain IFO 3294 exhibits 85\% homology with strain ATCC 19357, the type strain of the type species of the genus Gluconobacter and the reference strain for homology group I. Our study showed that strain IFO 3294 requires nicotinate for growth (Table 4), and this is a characteristic of group I gluconobacters. Yamada et al. (21) suggested that the strain IFO 3294 used by Gosselé et al. (11) was mixed with cells from a different homology group. The results of Micales et al. (14) support this suggestion.

When Gosselé et al. (10) examined the growth factor 
requirements of the gluconobacters, they found that nicotinate was required by $98 \%$ of the strains in phenon $B$ (homology group I of Micales et al.). Gosselé et al. (11) used tris(hydroxymethyl)aminomethane-maleate buffer adjusted to $\mathrm{pH} 5.4$ in their growth medium, but, when Micales attempted to repeat this experiment, he found that this buffer inhibited the growth of Gluconobacter strains (unpublished data). Therefore, we examined the requirement for nicotinate in the absence of buffer. Under these conditions, we found that all homology group I strains grew luxuriantly in the presence or absence of nicotinate after the first transfer from a yeast extract-containing medium. However, after three passages ( $24 \mathrm{~h}$ of incubation each) in media lacking nicotinate, all 20 strains grew to an OD of less than $1.0 \mathrm{U}$ after $24 \mathrm{~h}$ of incubation. On the other hand, if, after the third transfer, these strains were incubated for an additional $24 \mathrm{~h}$ (total, $48 \mathrm{~h}$ ), 18 of the strains reached an OD of $1.0 \mathrm{U}$ or more. This demonstrated that the homology group I strains did not have an absolute requirement for nicotinic acid, but, instead, their rate of growth appeared to be repressed in the absence of this vitamin.

Six strains placed in homology group I by Micales et al. (14) were also examined in the DNA-DNA homology study of Yamada et al. (23) (Table 4). Yamada et al. found that five of these strains exhibited 46 to $82 \%$ homology with the type strain of the type species of the genus, while the remaining strain, IFO 3275 , exhibited only $4 \%$ homology with the type strain of the type species and therefore was placed in their group b. However, Micales et al. found that strain IFO 3275 produces two colony types, which, when isolated, were found to belong to separate homology groups. One colony type, strain IFO 3275 a, has $42 \%$ homology with the genus type strain, and this strain was placed in homology group $I$. The second colony type, strain IFO 3275 b, has only $20 \%$ homology with the genus type strain but $97 \%$ homology with the reference strain for homology group III (Micales, M.S. thesis).

(ii) Reliability of phenotypic tests. Of the 20 homology group I strains examined in our study, only 2 (strains ATCC 23652 and IFO 3275a) grew to an OD of more than $0.5 \mathrm{U}$ within $24 \mathrm{~h}$, after three passages ( $24 \mathrm{~h}$ of incubation each) in a nicotinate-deficient medium. One of these two, strain ATCC 23652, reached an OD of approximately $0.95 \mathrm{U}$ within $24 \mathrm{~h}$ in the absence of nicotinate; however, it reached an OD of approximately $2.5 \mathrm{U}$ within $24 \mathrm{~h}$ in the presence of this vitamin. It was evident that the rate of growth of this strain was slower in the absence of nicotinate. Therefore, a slower growth rate in nicotinate-depleted cultures can be used to identify strain ATCC 23652 as a member of homology group I.

The second strain that grew to an OD of more than $0.5 \mathrm{U}$ in $24 \mathrm{~h}$ in a nicotinate-deficient medium, strain IFO 3275a, grew equally well in either the presence or the absence of nicotinate (OD, 0.6 to $0.8 \mathrm{U}$ ); however, this strain grew to an OD of only $0.5 \mathrm{U}$ or less in the presence of ribitol or arabitol as the primary carbon source. The DNA-DNA homology studies of Micales et al. (14) showed that this strain exhibits $42 \%$ homology with the reference strain for homology group I (also the type species of the genus). Growth to an OD of 0.5 $\mathrm{U}$ or less in medium containing ribitol or arabitol as the primary carbon source demonstrated that this strain is not in homology group II. However, using all of the phenotypic criteria established in this study, we were unable to determine whether this strain is a member of homology group I or homology group III. DNA-DNA homology is currently the only means of assigning strain IFO 3275a to a homology group. Therefore, further phenotypic characteristics should be examined to help identify this strain.

(iii) Designated species name. The type strain of the type species of the genus Gluconobacter (strain ATCC 19357 [= NCIB 9013]) was used as the reference strain for homology group I of Micales et al. (14); this strain is also found in homology group a of Yamada et al. (22) and phenon B of Gosselé et al. (11) (Table 4). Both Yamada et al. and Micales et al. previously proposed that the DNA-DNA homology groups containing this strain be called $G$. oxydans (Henneberg 1897) De Ley 1961. We believe that this name should be retained, although some of our data suggest that the species description given by DeLey and Swings (7) should be modified.

(iv) Description of Gluconobacter oxydans (Henneberg 1897) De Ley $1961,47^{\mathrm{AL}}$. Gluconobacter oxydans (Bacterium oxydans Henneberg 1897, 224) (ox'y.dans. Gr. adj. oxys, sharp, acid; L. part. adj. dans, giving; M.L. part. adj. oxydans, acid-giving, oxidizing). The characteristics are as given previously for the genus (7). In addition, all strains in this species form a DNA-DNA homology group when the type strain of the type species of the genus (ATCC 19357) is used as the reference strain $(14,22)$. When our methods are used, all strains grow to an OD of $1.0 \mathrm{U}$ or less after $24 \mathrm{~h}$ of incubation and three passages ( $24 \mathrm{~h}$ of incubation each) in nicotinate-deficient media (Table 4), and all strains grow to an $\mathrm{OD}$ of $0.5 \mathrm{U}$ or less in medium containing ribitiol or arabitol as the primary carbon source (Table 4). The guanine-plus-cytosine content of the DNA is 54 to $59 \mathrm{~mol} \%$ (14). Representative strains are ATCC 621, ATCC 621H, ATCC 9937, ATCC 14960, ATCC 23760, ATCC 23771, ATCC 33447, CIP 5714, CSIRO B1507, IFO 3244, IFO 3250, IFO 3293, IFO 3294, and IFO 12528. The designated type strain (7) is strain ATCC 19357.

Homology group II. (i) Comparison with previous studies. The strains which grew to an OD of $1.0 \mathrm{U}$ or more in medium containing ribitol or arabitol as the primary carbon source and after three transfers and $24 \mathrm{~h}$ of incubation in nicotinatedeficient media are members of homology group II of $\mathrm{Mi}$ cales et al. (14) (Table 4). Our study included 10 group II strains. Of these 10 strains, 8 were also previously examined in the phenotypic study of Gosselé et al. (11), who placed them in phenon A, the group which does not require nicotinate for growth. Since all 10 group II strains used in our study grew equally well in the presence and in the absence of this vitamin, our results agree with those of Gosselé et al. (11).

Of the 10 strains examined in this study, 8 were also examined previously in the DNA-DNA homology and phenotypic studies of Yamada et al. $(21,22)$. Using the membrane filter method, these authors showed that all eight strains (their group b) exhibited 1 to $24 \%$ homology with the type strain of the type species for the genus Gluconobacter (strain ATCC 19357). Using the S1 nuclease method, Micales found that these eight strains exhibited 16 to $26 \%$ homology with the type strain (Micales, M.S. thesis). Therefore, we concluded that homology group II is genetically quite different from $G$. oxydans.

(ii) Reliability of phenotypic tests. Because all 10 strains examined in homology group II reached an OD of $1.0 \mathrm{U}$ or more in medium containing ribitol or arabitol as the primary carbon source (Table 4), we believe that growth on these polyols can be used to reliably identify group II strains; 9 of the 10 strains examined also grew to an OD of $1.0 \mathrm{U}$ or more within $24 \mathrm{~h}$ after three passages ( $24 \mathrm{~h}$ of incubation each) in nicotinate-deficient media (Table 4). The remaining strain, 
IFO 3272 , grew to an OD of $0.5 \mathrm{U}$ or less within $24 \mathrm{~h}$ in the absence of nicotinate, but it grew to an OD of only $0.75 \mathrm{U}$ when this vitamin was present. Therefore, we suspect that other, as-yet-unidentified, growth factors are required for the best growth of strain IFO 3272 . Until the additional nutritional requirements are determined, we propose that growth in medium containing ribitol and growth in medium containing arabitol are the most reliable tests for identifying homology group II strains.

(iii) Comparison with $G$. cerinus and proposed species name. Yamada and Akita (21) validly published the name $G$. cerinus for strains in their homology group b. Since 8 of the 10 homology group II strains that we examined (Table 4) were included in group b of Yamada and Akita, we initially felt that the homology group II strains described by Micales et al. (14) should be called $G$. cerinus. On the other hand, Yamada and Akita (21) designated strain IFO 3267 (= ATCC 19441) as the type strain of $G$. cerinus. Micales et.al. (14), using the $\mathrm{S} 1$ nuclease method, found that this type strain (ATCC 19441) was only $23 \%$ homologous with the group II reference strain (IFO $3264^{\mathrm{T}}$ ), whereas all other strains in group II were between 44 and $87 \%$ homologous with group II reference strain IFO $3264^{\mathrm{T}}$. Further studies are needed to explain the apparent inconsistencies in these two DNADNA homology studies. At the present time, however, the designated type strain (21) of $G$. cerinus (strain IFO 3267 [= ATCC 19441]) appears to be genetically distinct from the homology group II gluconobacters (14). Therefore, we cannot use the name $G$. cerinus to represent the group II gluconobacters. Instead, we propose that the name Gluconobacter frateurii sp. nov. be used for this species.

(iv) Description of Gluconobacter frateurii sp. nov. Gluconobacter frateurii (fra.teur'i.i. M.L. n. frateurii, of Joseph Frateur [1903-1974], eminent Belgian microbiologist, who is well known for his classic study of the acetic acid bacteria [8]). The characteristics are as given previously for the genus (7). In addition, all strains in this species form a DNA-DNA homology group when strain IFO $3264^{\mathrm{T}}$ is used as the reference strain (14). When our methods are used, all strains grow to an OD of $1.0 \mathrm{U}$ or more after $24 \mathrm{~h}$ of incubation and three passages ( $24 \mathrm{~h}$ of incubation each) in nicotinatedeficient media (except strain IFO 3272, which seems to have unusual nutritional requirements [Table 4]), and all strains grow to an OD of $1.0 \mathrm{U}$ or more after $24 \mathrm{~h}$ when either ribitiol or arabitol is the primary carbon source (Table 4). The guanine-plus-cytosine content of the DNA is 53 to 55 mol\% (14). Representative strains are ATCC 12302, ATCC 15178, ATCC 15180, IFO 3251, IFO 3254, IFO 3268, IFO 3270 , and IFO 3286. The type strain is strain ATCC 49207 (= IFO 3264).

(v) Further description of the type strain. When grown as described in Materials and Methods, strain ATCC $49207^{\mathrm{T}}(=$ IFO $3264^{\mathrm{T}}$ ) forms cream-colored colonies that have convex elevations, glistening surfaces, a granular internal appearance, slightly undulating edges, and diameters of $1 \mathrm{~mm}$. In addition to having the characteristics described previously for the genus (7), strain ATCC $49207^{\mathrm{T}}$ has the following characteristics: (i) $21 \%$ DNA-DNA homology with the type strain of the genus, strain ATCC 19357 (Micales, M.S. thesis); (ii) $30 \%$ DNA-DNA homology with group III reference strain, IFO 3276a (14); and (iii) 70\% DNA-DNA homology with strain ATCC $12302(14)$, another group II strain $(G$. frateurii). When strain ATCC $49207^{\mathrm{T}}$ is grown according to our methods, it has the following characteristics: grows to an OD of $1.5 \mathrm{U}$ or more after three passages $(24 \mathrm{~h}$ of incubation each) in nicotinate-deficient media (Table 5); and grows to an
OD of $2.5 \mathrm{U}$ or more after $24 \mathrm{~h}$ of incubation in media containing ribitol or arabitol as the primary carbon source (Table 3). In addition to the five differential characteristics noted above, when strain IFO $3264^{\mathrm{T}}$ is grown according to our methods, it has the following additional properties (L. M. Jones-Mason, M.S. thesis, Virginia Polytechnic Institute and State University, Blacksburg, 1987): grows to an $\mathrm{OD}$ of more than $1.0 \mathrm{U}$ within $24 \mathrm{~h}$ in media containing glucose or myo-inositol as the primary carbon source; grows to an OD of more than $3.0 \mathrm{U}$ within $24 \mathrm{~h}$ in media containing xylitol but fails to grow to an OD of more than $0.40 \mathrm{U}$ within $24 \mathrm{~h}$ in media containing sucrose as the primary carbon source; grows to an OD of $0.90 \pm 0.17 \mathrm{U}$ after $48 \mathrm{~h}$ of incubation in media containing $17 \%$ glucose; and grows to an OD of $1.85 \pm 0.17 \mathrm{U}$ after $48 \mathrm{~h}$ of incubation in medium $(1 \%$ mannitol, $1 \%$ yeast extract, $1 \%$ peptone) containing $1.0 \%$ $\mathrm{NaCl}$.

Homology group III. (i) Comparison with previous studies. We examined the phenotypic characteristics of five strains previously placed in homology group III (14). Micales found that these strains have only 13 to $23 \%$ homology with the Gluconobacter type species (Micales, M.S. thesis), but they have $71 \%$ or more homology with strain IFO $3276 \mathrm{a}$, the reference strain used to construct homology group III (14). Three of these five strains were previously examined in the phenotypic study of Gosselé et al. (11), who showed that these strains do not require nicotinate for growth (phenon A). Since the growth of four of five homology group III strains was unaffected by nicotinate (Table 4), our results appeared to support those of Gosselé et al.

(ii) Reliability of phenotypic tests. Two of the five strains examined in homology group III had phenotypic characteristics resembling those of strains in homology group I or homology group II. The first strain, IFO 3297a, grew to an OD of only $0.5 \mathrm{U}$ within $24 \mathrm{~h}$ after three passages $(24 \mathrm{~h}$ of incubation each) in nicotinate-deficient media, and it grew to an OD of only $0.5 \mathrm{U}$ or less in medium containing either ribitol or arabitol as the primary carbon source (Table 4). When these phenotypic characteristics alone were used, it appeared that this strain was a member of homology group I, G. oxydans. However, this strain exhibits $77 \%$ homology with the reference strain for homology group III (14); thus, it must be assigned to this group. If we used only the three phenotypic tests which appear to be most differential for Gluconobacter species, we were unable to correctly identify strain IFO 3297a as a group III gluconobacter. On the other hand, strain IFO $3297 \mathrm{a}$ is the only strain which we tested that increased the $\mathrm{pH}$ of the medium from 6.0 to 7.0 or more when it was grown in medium containing mannitol, sorbitol, ribitol, myo-inositol, or lactose, and this strain was the only strain to grow to an $\mathrm{OD}$ of $1.0 \mathrm{U}$ or more at $37^{\circ} \mathrm{C}$. Therefore, alkalinization of polyol media or growth at $37^{\circ} \mathrm{C}$ can be used to identify strain IFO $3297 \mathrm{a}$ as an unusual member of homology group III.

The second unusual group III strain, IFO 3265, reached an OD of $1.0 \mathrm{U}$ or more within $24 \mathrm{~h}$ after three passages in nicotinate-deficient media, and it grew to an OD of more than $1.0 \mathrm{U}$ in the presence of ribitol or arabitol as the primary carbon source (Table 4). These results imply that this strain should be a member of homology group II, $G$. frateurii. However, the DNA-DNA homology studies of Micales et al. (14) demonstrated that strain IFO 3265 exhibits both an identical homology with the reference strain for homology group III (colony variant a of strain IFO $3276^{\mathbf{T}}$ ) and $65 \%$ homology with the reference strain for homology group II (strain IFO $3264^{\mathrm{T}}$ ). As Micales et al. suggested (14), it 
appears that strain IFO 3265 is a mixture of homology group II and homology group III strains that exhibit identical colony types. So far, we have been unable to separate this apparent mixture. Until separation is achieved and confirmed through DNA homology studies, we recommend that strain IFO 3265 not be used for taxonomic studies.

(iii) Proposed species name. The DNA-DNA homology study of Micales et al. (14) demonstrated that group III gluconobacters are genetically different from gluconobacters in homology groups I and II. Our results demonstrate that there are also distinct phenotypic differences between the strains in group III and the strains in groups I and II (Table 4). Therefore, we agree with Micales et al. that the group III gluconobacters should be considered a separate species, and we propose the name Gluconobacter asaii $\mathrm{sp}$. nov. for these organisms.

(iv) Description of Gluconobacter asaii sp. nov. Gluconobacter asaii (a.sa'i.i. M.L. n. asaii, of Toshinobu Asai, eminent Japanese microbiologist who was the first to distinguish gluconobacters from other acetic acid bacteria, who named this genus, and who spent most of his professional life studying these microorganisms [2]). The characteristics are as given previously for the genus (7). In addition, all strains in this species form a DNA-DNA homology group when colony variant a of strain ATCC $49206^{\mathrm{T}}\left(=\right.$ IFO $\left.3276^{\mathrm{T}}\right)$ is used as the reference strain (14). When our methods are used, all strains grow to an OD of $1.0 \mathrm{U}$ or more after $24 \mathrm{~h}$ of incubation and three passages ( $24 \mathrm{~h}$ of incubation each) in nicotinate-deficient media (except strain IFO 3297a, which can be characterized by its unique alkalinization of media during growth on mannitol, ribitol, or arabitol), and all strains fail to grow beyond an OD of $0.5 \mathrm{U}$ after $24 \mathrm{~h}$ when either ribitol or arabitol is used as the primary carbon source (Table 4). The guanine-plus-cytosine content of the DNA is 52 to 55 mol\% (14). Representative strains are ATCC $49206^{\mathbf{T}}$ (referred to as genetically identical colony variants IFO $3276 \mathrm{a}$ and IFO 3276b by Micales et al. [14]) and ATCC 43781 (referred to as strain RS203b by Micales et al. [14]). The type strain is ATCC 49206 (= IFO 3276).

(v) Further description of the type strain. Strain IFO $3276^{\mathrm{T}}$ (as received) contained two genetically identical colony variants, which were called IFO $3276 \mathrm{a}$ and $3276 \mathrm{~b}$ by Micales et al. (14). When grown as described in Materials and Methods, colony variant a forms cream-colored, opaque colonies that have convex elevations, glistening, smooth surfaces, entire edges, and diameters of $0.25 \mathrm{~mm}$; when observed from underneath, the colonies exhibit brightly highlighted edges that extend about one-fourth of the way across the colony diameter. In contrast, when colony variant b is grown in the same way, it forms more translucent colonies having diameters of $0.50 \mathrm{~mm}$ and lacking brightly highlighted edges when viewed from underneath.

Colony variants $\mathrm{a}$ and $\mathrm{b}$ were easily separated by Micales et al. (14), and each variant kept its colony characteristics through many transfers and storage on either slants or $66 \%$ glycerol during the study reported here. The DNA-DNA homology study (14) demonstrated that colony types a and b are genetically identical colony variants, and our studies show that they have the same diagnostic phenotypic characteristics. Note, however, that colony variant purity has not been easy to maintain or reachieve. For example, when colony variant a was purified, stored in liquid nitrogen for 5 years, and then recently streaked for purity, about $25 \%$ of the separated colonies were colony variant $b$; after eight subsequent transfers, we were unable to achieve separation of the two colony variants. Strain IFO $3276^{\mathrm{T}}$ (containing colony variants a and b) has been deposited with the American Type Culture Collection as strain ATCC $49206^{\mathrm{T}}$.

In addition to having the characteristics described previously for the genus (7), strain ATCC $49206^{\mathrm{T}}$ (colony variant IFO 3276a) has six differential characteristics. The following three characteristics were previously demonstrated by $\mathrm{Mi}^{-}$ cales et al:: (i) $14 \%$ DNA-DNA homology with the type strain of the type species of the genus, strain ATCC 19357 (Micales, M.S. thesis); (ii) $22 \%$ DNA-DNA homology with the group II ( $G$. frateurii) reference strain IFO $3264^{\mathrm{T}}(14)$; and (iii) 70\% DNA-DNA homology with strain RS203b (14), another group III strain $(G$. asaii) recently deposited with the American Type Culture Collection as strain ATCC 43781. Three other characteristics of colony variant IFO 3276 a were demonstrated in the work reported here. When colony variant IFO $3276 \mathrm{a}$ is grown according to our methods, it grows to an OD of $1.9 \mathrm{U}$ or more after three passages ( $24 \mathrm{~h}$ of incubation each) in nicotinate-deficient media (Table 5 ); it grows to an OD of $0.31 \mathrm{U}$ or less after $24 \mathrm{~h}$ of incubation in media containing ribitol (Table 3); and it fails to grow on arabitol as the primary carbon source (Table 3 ). The latter three characteristics were also found with colony variant IFO 3276b (Jones-Mason, M.S. thesis), except that the growth of colony variant $b$ on ribitol was slightly greater (OD varied from 0.36 to $0.47 \mathrm{U}$ in three separate experiments).

In addition to the six differential characteristics noted above, Mason (Jones-Mason, M.S. thesis) demonstrated that colony variant IFO 3276a has the additional properties described below (when it is grown according to our methods). When myo-inositol, glucose, and xylitol are used separately as the primary carbon sources, this strain grows to OD values of more than $0.9,1.6$, and $2.3 \mathrm{U}$, respectively, within $24 \mathrm{~h}$. However, this colony variant does not grow to OD values of more than $0.25 \mathrm{U}$ after $24 \mathrm{~h}$ in media containing sucrose as the primary carbon source. In media containing $17 \%$ glucose or $1.0 \% \mathrm{NaCl}$, the colony variant grows to OD values of 1.40 or $2.13 \mathrm{U}$, respectively, after $48 \mathrm{~h}$ of incubation.

\section{ACKNOWLEDGMENTS}

This study was supported in part by a grant-in-aid of research from Sigma Xi, The Scientific Research Society, and by graduate fellowships (awarded to LMM) from the Virginia State Council of Higher Education (1985-87). We thank Polly Olinger for performing the temperature studies and J. O. Falkinham, III and N. R. Krieg for many helpful suggestions given during the course of this study.

\section{LITERATURE CITED}

1. Ameyama, M. 1975. Gluconobacter oxydans subsp. sphaericus, new subspecies isolated from grapes. Int. J. Syst. Bacteriol. 25:365-370.

2. Asai, T. 1968. Acetic acid bacteria: classification and biochemical activities. University Park Press, Baltimore.

3. Asai, T., and K. Shoda. 1958. The taxonomy of Acetobacter and allied oxidative bacteria. J. Gen. Appl. Microbiol. 4:289-311.

4. DeLey, J. 1961. Comparative carbohydrate metabolism and a proposal for the phylogenetic relationship of the acetic acid bacteria. J. Gen. Microbiol. 24:31-50.

5. DeLey, J., and J. Frateur. 1974. Family I. Pseudomonadaceae. Genus IV. Gluconobacter Asai 1935, 689, emend, mut. char. Asai, Iizuka and Komagata, 1964, 100, p. 251-253. In R. E. Buchanan and N. E. Gibbons (ed.), Bergey's manual of determinative bacteriology, 8th ed. The Williams \& Wilkins Co., Baltimore.

6. DeLey, J., M. Gillis, and J. Swings. 1984. Family VI. Acetobacteraceae Gillis and De Ley 1980, 23, p. 268. In N. R. Krieg and J. G. Holt (ed.), Bergey's manual of systematic bacteriology, vol. 1. The Williams \& Wilkins Co., Baltimore. 
7. DeLey, J., and J. Swings. 1984. Genus Gluconobacter Asai 1935, 689, emend. mut. char. Asai, Iiquka and Komagata 1964, 100, p. 275-278. In N. R. Krieg and J. G. Holt (ed.), Bergey's manual of systematic bacteriology, vol. 1. The Williams \& Wilkins Co., Baltimore.

8. Frateur, J. 1950. Essai sur la Systématique des Acetobacters. Cellule 53:287-392.

9. Gherna, R. 1978. Media formulations, p. 432. In R. Gherna, W. Nierman, and P. Pienta (ed.), The American Type Culture Collection Catalogue of Strains I, 13th ed. American Type Culture Collection, Rockville, Md.

10. Gosselé, F., J. Swings, and J. DeLey. 1980. Growth factor requirements of Gluconobacter. Zentralbl. Bakteriol. Microbiol. Hyg. Abt. 1 Orig. Reihe C 1:348-350.

11. Gosselé, F., J. Swings, K. Kersters, and J. DeLey. 1983. Numerical analysis of phenotypic features and protein gel electropherograms of Gluconobacter Asai 1935 emend. mut. char. Asai, Iizuka, and Komagata 1964. Int. J. Syst. Bacteriol. 33:65-81.

12. Greenfield, S., and G. W. Claus. 1972. Nonfunctional tricarboxylic acid cycle and the mechanism of glutamate biosynthesis in Acetobacter suboxydans. J. Bacteriol. 112:1295-1301.

13. Loitsyanskaya, M. S., G. V. Pavlenko, and A. I. Ivchenko. 1979. Taxonomy of acetic acid bacteria. Mikrobiologiya (Engl. Transl.) 48:545-551.

14. Micales, B. K., J. L. Johnson, and G. W. Claus. 1985. Deoxyribonucleic acid homologies among organisms in the genus Gluconobacter. Int. J. Syst. Bacteriol. 35:79-85.

15. Rao, M. R. R., and J. L. Stokes. 1953. Nutrition of the acetic acid bacteria. J. Bacteriol. 65:405-412.
16. Saito, H., and K. I. Miura. 1963. Preparation of transforming deoxyribonucleic acid by phenol treatment. Biochim. Biophys. Acta 72:619-629.

17. Smibert, R. M., and N. R. Krieg. 1981. General characterization, p. 409-449. In P. Gerhardt, R. G. E. Murray, R. N. Costilow, E. W. Nester, W. A. Wood, N. R. Krieg, and G. B. Phillips (ed.), Manual of methods for general bacteriology. American Society for Microbiology, Washington, D.C.

18. White, S. A., and G. W. Claus. 1982. Effect of intracytoplasmic membrane development on oxidation of sorbitol and other polyols by Gluconobacter oxydans. J. Bacteriol. 150:934-943.

19. Yamada, Y., K. Aida, and T. Uemura. 1968. Distribution of ubiquinone 10 and 9 in acetic acid bacteria and its relation to the classification of genera Gluconobacter and Acetobacter, especially of so-called intermediate strains. Agric. Biol. Chem. 32:786-788.

20. Yamada, Y., K. Aida, and T. Uemura. 1969. Enzymatic studies on the oxidation of sugar and sugar alcohol. V. Ubiquinone of acetic acid bacteria and its relation to classification of genera Gluconobacter and Acetobacter, especially of the so-called "intermediate" strains. J. Gen. Appl. Microbiol. 15:181-196.

21. Yamada, Y., and M. Akita. 1984. An electrophoretic comparison of enzymes in strains of Gluconobacter species. J. Gen. Appl. Microbiol. 30:115-126.

22. Yamada, Y., N. Itakura, M. Yamashita, and Y. Tahara. 1984. Deoxyribonucleic acid homologies in strains of Gluconobacter species. J. Ferment. Technol. 62:595-600.

23. Yamada, Y., M. Nunoda, T. Ishikawa, and Y. Tahara. 1981. The cellular fatty acid composition in acetic acid bacteria. J. Gen. Appl. Microbiol. 27:405-418. 